\title{
The Determinants of Child Labor in MINT Countries: Dynamic Panel Data Analysis
}

\section{Süreyya İmre*}

\begin{abstract}
There are many studies in the literature on child labor. However, most of these studies are based on statistics on children, or the factors that cause child labor are explained as economic concepts. The purpose of this study is to investigate the reasons why school-age children adopt the role of "child laborer" and determine the effects of these factors. In this context, in order to examine the factors affecting child labor in developing countries, this study has tried to determine the factors causing child labor with dynamic panel data analysis using MINT Countries data for the period of 1990-2018. The countries' development levels and poverty are closely related to child labor. For this reason, the human development index is added to the model as a dependent variable. Considering the studies in the literature, population growth, primary school enrollment rate, primary school duration, and labor force participation rate variables were added to the model as independent variables. At the end of the analysis, all variables were found to be statistically significant. The effect of population growth and the number of primary school students on the human development index was negative, while the effect of other variables was positive.
\end{abstract}

\section{Keywords}

Dynamic panel data models, MINT Countries, Child labor

\section{JEL Classification}

B23, C23, 124

** Corresponding author: Süreyya Imre (Res. Asst.), Istanbul Gelisim University, Faculty of Economic Administrative and Social Sciences, Management Information Systems, Istanbul, Yurkey. E-mail: simre@gelisim.edu.tr ORCID: 0000-0001-8904-6635

To cite this article: Almre, S. (2021). The determinants of child labor in MINT countries: dynamic panel data analysis. EKOIST Journal of Econometrics and Statistics, 34, 57-72. https://doi.org/10.26650/ekoist.2021.34.912176 


\section{Introduction}

When examining the issue of human development, it is necessary to evaluate quantitative and qualitative indicators together. Over the years, many societies have seen remarkable advances in human development. For example, many more children started to receive primary education compared to previous years and a high schooling rate was achieved. But if these primary school children can't read and write properly, this of course does not represent sustainable human progress (Ataseven and Bakış, 2016).

"Child" is basically defined as a person who does not bear the burden of life, is protected by the family and the state, is protected by other institutions and organizations, can live out his childhood, can complete his physical and mental development in a healthy way, is prepared for the future with adequate education, and constitutes the qualified workforce of the future (Avşar and Öğ̈̈toğulları, 2012).

How the concept of child is perceived by societies is as important as its definition. According to the traditional understanding in underdeveloped economies, a child is more than just a younger member of the family. A child is seen as a potential worker who can contribute to the economic development of the family, and a social security tool in the later years of the family. In this understanding, the child is perceived as a free labor force, the only capital of poor people. In developed countries and families living here, the child is as an asset that is kept away from working life while giving the family the feeling of being a family and preparing for the future (Avşar and Öğ̈̈toğulları, 2012).

The concept of child labor differs from country to country and even from region to region in societies with different social structures and levels of development. According to the International Labor Organization's definition, child labor is the employment of children in jobs that deprive them of their childhood, potential, and dignity and that harm their physical and mental development. While the International Labor Organization considers the 15-24 age group to be young, it defines workers under the age of 15 as "child workers" or "working children" who contribute to the family income or earn a living (Kulaksız, 2014).

While poverty is the primary cause of child labor, there are numerous other social and economic reasons for it, including unemployment, education level, population growth,limited employment opportunities, disruptions in the education system, migration, insufficient social awareness, and inadequacy of legal regulations (Çöpoğlu, 2018). In fact, these factors are concepts that are constantly encountered as either the cause or the result of poverty.

If child labor occurs not because of parents' selfishness but because of concerns about household survival, the popular argument for outlawing child labor loses much 
of its force (Basu and Hoang, 1998). Insufficient income and economic difficulties cause families to direct their children to working life. The involvement of children in working life sometimes causes them to completely break away from educational life, and sometimes to carry out both school life and working life together. In both these cases, children find themselves in a vicious cycle that they will probably live in for the rest of their lives because they are far from the knowledge they need.

Employers prefer to employ child workers because they receivenlower wages than adult workers, and are docile, easily obeying orders (Taş and Abbasigil, 2017). Child laborers work in harsh conditions such as agriculture, manufacturing, fishing, construction, and street sales (Osment, 2014). Physical work done with heavy physical force can cause permanent damage to the body by retarding the biological development of the child. Working under adverse conditions also harms their psychological development.

Child labor is a phenomenon that harms the educational life of the child. Because working children cannot attend school most of the time, the educational success of children who go to school and work is negatively affected. The child who cannot complete his education will have a very low chance of getting out of this vicious social cycle for the rest of his life and will continue to be under the pressure of a certain environment (Bulutay, 1995). The fact that children are away from family control and protection while working puts their safety at risk. This causes them to be open to all kinds of exploitation and abuse.

Education is a very important part of development. Children who turn to child labor are driven mainly by economic deprivation, lack of schooling, and lack of family involvement in meeting their daily needs. Studies have found low enrollment rates with increasing child employment rates. Schools are an early intervention platform against child labor because they restrict children's participation in mundane work. The obstacles to this approach are economic. Children will not be able to go to school unless economic change is achieved. Child labor can be controlled through economic development, raising awareness making education affordable at all levels, and enforcing anti-child labor laws (Srivastava,2011).

In addition to families' education and income level, there is another very important variable among the causes of child labor in societies. This variable is the value placed on children in the country. If the members of a society see a low level of education as sufficient and see the child's work as a normal and natural process, children in that society will continue to work (Erbay, 2013).

The problem of child labor is not unique to underdeveloped countries, but different examples are also encountered in western economies that have completed their industrialization process. Studies show that there is a vicious cycle among almost all 
the criteria for underdevelopment and child employment, and this relationship plays a major role in the perpetuation of underdevelopment (Tunçcan, 1999). In the light of these data, it is clear that the problem of child labor cannot be separated from the socio-economic problems of the country in general and that the countermeasures require wide-ranging policies.

The other parts of this paper are as follows. Part 2 is a literature review on child labor and dynamic panel data analysis. Part 3 is the econometric methodology. Part 4 is the method and findings. The paper concludes with Part 5.

\section{Literature Review}

There are numerous studies in the literature on child labor. However, all of these studies are based on statistics on child labor, or the factors that cause child labor are explained conceptually. This section includes studies conducted with dynamic panel data models and studies on child labor and presenting statistical data.

Baland and Robinson (2000): In this study, a child labor model was created and its effects on welfare were investigated. It has been assumed that there is a reciprocal relationship between child labor and human capital accumulation. At the same time, the effects of a simple child labor ban on child labor in enterprises was examined. Finally, the study found that the effects of child labor on fertility are uncertain.

Kooshki and Rahman (2001): In this study, it was estimated whether information and communication technologies are effective on growth in OECD, BRICS, and NICS countries. In the analysis, which used the Cobb-Douglas production function and 1990-2008 annual data, the relationship between variables was investigated using fixed effects and dynamic panel data methods. From both analyses, it was found that information and communication technologies have a positive effect on growth. Based on the results they obtained, the researchers stated that these technologies play a critical role in the growth process and therefore countries that want to accelerate their growth should increase their investment in these technologies.

Edmonds and Pavcnik's (2005) study discussed how to answer the question of how trade liberalization affects children's employment in developing economies. Trade theory predicts that an increase in the price of exported goods can increase or decrease child labor depending on the magnitude of the substitution and income effects. In this study, the relationship between changes in the relative price of an exported good and child labor is analyzed using household-level data in a poor country. In particular, they associated child labor with the regional and intertemporal variation in the price of actual rice surrounding the national and international rice market integration in Vietnam. Higher rice prices were found to be associated with a decline in child labor. Income effects played an important role in this relation. They 
concluded that the increases in rice prices are associated with the largest decreases in child labor in households with large net rice producers. These findings suggest that more market integration can be attributed to less child labor.

Erdil, Türkcan, and Yetkiner (2009) tested the effect of information and communication technologies on growth in 131 underdeveloped and developing countries using data from 1995-2006. According to the results obtained from analysis using the GMM method, information and communication technologies have a positive effect on economic growth in underdeveloped and developing countries.

Choi (2010) investigated the effect of the internet on service trade for 151 countries using pooled OLS regression, the fixed effects model, and panel GMM, and found a positive effect at the end of the study. According to the results of the research, doubling internet usage in a country causes an increase of $2 \%$ to $4 \%$ in service trade.

Zeren and Ergün (2010): In this study, in order to determine the factors that play a role in foreign direct investment inflows to European Union countries, dynamic panel data analysis was applied with data from the period 1995-2007. At the end of the analysis, it was concluded that the gross domestic product growth rate, openness ratio, and development level have a positive effect on foreign direct investment inflows. It was determined that current account balance and gross capital accumulation are negatively related to foreign direct investments.

Fooladi, Rahmah, and Masood (2012) estimated the relationship between growth and information and communication technologies using data from 159 countries with different income levels for the period 2000-2009. According to the results of the analysis using the GMM method, one of the dynamic panel data approaches, the positive effect on growth of information and communication technologies changes depending on the income levels of the countries and this positive effect increases as the income level rises. Based on these results, researchers have stated that technological developments have a key role in growth.

Avşar and Öğ̈̈toğulları (2012): This study touched on the concept of child labor, the causes and drawbacks of child labor, its historical development, and strategies to combat it. In addition, statistics on the current situation of child labor in our country were presented.

Efe and Uluoğlu (2015) aimed to determine what point has been reached in the reduction of child labor in the world and to make some predictions for the future by revealing the determinants of child labor in the light of ILO reports.

Hayaloğlu (2015): In this study, in order to investigate the effect of financial development on economic growth in the Fragile Five Countries, the dynamic panel data analysis technique was used with data from the period 1990-2012. The findings obtained in the study, where the variables of domestic loans to the private sector, 
domestic loans given to the private sector by banks, population size, trade (export and import), foreign direct investments, and gross capital formation were used as indicators, show that veriables have a positive effect on economic growth.

Berigel and Eroğlu (2019): This study showed factors such as poverty, unemployment, informal economy, characteristics of parents and households, lack of supervision, education, and migration rate as the causes of child labor. Based on basic child labor indicators, child labor in Turkey was analyzed and some suggestions for the solution of child labor were offered.

\section{Econometric Methodology}

Since the economic behavior in a period is largely influenced by past experiences and old behavior patterns, it is very important to consider lagged values of variables as explanatory factors when examining economic relations. Dynamic structure is also frequently used in panel data models. Dynamic panel data models are examined under two headings: The first is autoregressive panel data models with the lagged value of the dependent variable included in the model as an explanatory variable, and the second is distributed lagged panel data models with the lagged values of the explanatory variables included in the model.

Autoregressive panel data model is shown below:

$$
\begin{aligned}
& \mathrm{Y}_{\mathrm{it}}=\delta \mathrm{Y}_{\mathrm{it}-1}+\beta \mathrm{X}_{\mathrm{it}}+\mathrm{v}_{\mathrm{it}} \\
& \mathrm{v}_{\mathrm{it}}=\mu_{\mathrm{i}}+\mathrm{u}_{\mathrm{it}}
\end{aligned}
$$

When estimating dynamic panel data models, two different features should be considered for the selection of the appropriate method. The first is whether the error terms are autocorrelated and the other is whether the dependent variables are fully exogenous (Akay, 2018). Some problems may arise in estimators in estimating these models with known estimation methods. Generally, in dynamic models, it is known that $Y_{i t-1}$ is correlated with $u_{i t-1}$ due to past shocks. Also, in panel data models, $Y_{i t}$ is a function of $\mu_{\mathrm{i}}$ ', so $\mathrm{Y}_{\mathrm{it}-1}$ is a function of $\mu_{\mathrm{i}}$. Therefore, $\mathrm{Y}_{\mathrm{it}-1}$ is correlated with the error term including $\mu_{\mathrm{i}}$. In this case, the rigid externality assumption is broken.

Therefore, dynamic panel data models provide deviating and inconsistent estimates with the Pooled Least Squares Method. Likewise, random effects should deviate from the Generalized Least Squares Estimators because the unit effect $\mu_{\mathrm{i}}$ included in the error term is correlated with the independent variable $\mathrm{Y}_{\mathrm{it}-1}$, and the assumption of $\mathrm{E}\left(\mathrm{X}_{\mathrm{it}} \mu_{\mathrm{i}}\right)=0$ of the random effects model is broken.

In this context, the estimation of the dynamic model with the assumption of random effects is inconsistent. For all these reasons, Fixed Effects and First Difference 
Estimators are used in the estimation of dynamic panel data models, which mostly consider unit effects and allow the relationship between unit effects and independent variables. With the first difference transformation, the unit effect $\mu_{\mathrm{i}}$ falls out of the model. However, the lagged dependent variable is endogenous, so estimates with bias are obtained. Therefore, the correlation between the lagged dependent variable and the error term should be checked with the instrument variable after the first difference transformation is made. In order to eliminate these problems, GMM method has been proposed in dynamic panel estimates. This method is widely used in the estimation of dynamic models, as it is based on relatively simple assumptions regarding the ease of application and the tool necessary for estimation. Among the estimators based on the GMM method, it would be more appropriate to use Arellano and Bond's Generalized Moments (GMM) Estimator (Arellano and Bond, 1991). This estimation method creates moment conditions by assuming that the future values of the error are not correlated with the present values of the explanatory variables (Akbulut, 2013).

There are two different GMM estimates, one-stage and two-stage. In a stepwise estimation, the error terms are assumed to be homoscedastic with constant variance between groups and over time. In the two-stage estimation, it is taken into account that the error terms may be heteroscedastic. In the second stage, the residuals of error obtained from the first stage are used to create a consistent estimation of the variance covariance matrix, so the two-stage estimation gives more efficient results asymptotically (Khadraoui, 2012).

Arellano and Bond's GMM Estimator is an instrument variable method suitable for panel data models that show dynamical characteristics in which there is a linear relationship between these variables and the existence of strict non-external explanatory variables. In models with fixed effects, autocorrelation and changing variance are used only in the cross section (Roodman, 2006).

As stated before, since the lagged value of the dependent variable is related to the error term, an endogeneity problem arises. With the first difference transformation, the unit effect is excluded from the model, but the lagged dependent variable is intrinsic. Due to the correlation between $\mathrm{Y}_{\mathrm{it}-1}$ and $\varepsilon_{\mathrm{it}-1}, \mathrm{Y}_{\mathrm{it}-1}, \mathrm{Y}_{\mathrm{it}-2 \text {, and } \varepsilon_{\mathrm{it}-1} \varepsilon_{\mathrm{it}-2} \text { are }}$ not orthogonal. Bias estimators are obtained. Therefore, the correlation between $Y_{i t-1}$ and $\varepsilon_{\mathrm{it}-1}$ should be controlled by the use of instrument variables (Tatoğlu,2013).

In this estimation method, the first differentiated model is transformed with the help of the instrument variable matrix and the estimation is made by the generalized least squares method. For this reason, the Generalized Moments Estimator is known as the "Two-Stage Instrument Variables Estimator." Consider the following equations:

$$
\begin{aligned}
& \mathrm{Y}_{\mathrm{it}}=\gamma \mathrm{Y}_{\mathrm{it}-1}+\mathrm{v}_{\mathrm{it}} \\
& \mathrm{v}_{\mathrm{it}}=\mu_{\mathrm{i}}+\varepsilon_{\mathrm{it}}
\end{aligned}
$$


As can be seen, in the equation whose first difference is taken, the unit effect has been dropped from the model.

$$
\mathrm{Y}_{\mathrm{it}}-\mathrm{Y}_{\mathrm{it}-1}=\gamma\left(\mathrm{Y}_{\mathrm{it}-1}-\mathrm{Y}_{\mathrm{it}-2}\right)+\left(\varepsilon_{\mathrm{it}}-\varepsilon_{\mathrm{it}-1}\right)
$$

Here $\mathrm{Y}_{\mathrm{it}-1}$ and $\varepsilon_{\mathrm{it}-1}$ are correlated, and error term $\left(\varepsilon_{\mathrm{it}}{ }^{-} \varepsilon_{\mathrm{it}-1}\right) \mathrm{MA}(1)$ is unit root. The first difference estimator is obtained with bias.

General form of Generalized Moments Estimator (GMM) is as follows;

$$
\left.\widehat{\mathrm{\gamma}}_{\mathrm{GMM}}=\left(\Delta X^{\prime} \mathrm{W}\right)\left(W^{\prime} \widehat{\Omega} \mathrm{W}\right)^{-1} W^{\prime} \Delta \mathrm{X}\right)^{-1}\left(\Delta X^{\prime} \mathrm{W}\left(W^{\prime} \widehat{\Omega} \mathrm{W}\right)^{-1} W^{\prime} \Delta \mathrm{Y}\right.
$$

$\widehat{\Omega}$ is the variance covariance matrix of the error terms obtained from the difference equations, and $\mathrm{W}$ is the valid instrument variables in the difference equations.

\section{Testing the Assumptions}

Some assumptions should be provided for the reliability of estimation methods in dynamic panel data models. Basic tests used to examine these assumptions will be discussed here.

Since the lagged dependent variable is among the independent variables in dynamic panel data models, there is an endogeneity problem. In this case, the presence of endogeneity must be tested. The Wu-Hausman Endogeneity Test is used to test the endogeneity. Hypotheses;

$\mathrm{H}_{0}=$ Variables are exogenous.

$\mathrm{H}_{1}=$ Variables are endogenous.

To test the externality, the $\mathrm{F}$ distributed Wu-Hausman test is recommended. If it is decided that the variable is endogenous at the end of the test, instrument variables should be used.

Testing the validity of instrument variables and testing the existence of second-order correlation in the residuals of the first differentiated model is a necessary condition for the residuals to be healthy. For this reason, there are a number of specification tests that should be done during the estimation of dynamic panel data models.

The Sargan Test is used to test whether the instrument variables are valid. If the instrument variables are intrinsic, the error terms and explanatory variables are correlated. The Sargan test is the first difference and system test of Arellano and Bond and the tool used in the generalized estimation of moments, which tests the validity of all variables (Tatoğlu, 2013). 
The null and alternative hypothesis valid in the Sargan test is expressed as follows;

$\mathrm{H}_{0}$ : Instrument variables are exogenous. Extreme identification constraints apply.

$\mathrm{H}_{1}$ : Instrument variables are endogenous. Excessive definition constraints are invalid.

The test statistic distributes $\chi^{2}$ with $\mathrm{p}-\mathrm{k}-1$ degrees of freedom. The null hypothesis is rejected if the account value $\chi^{2}$ exceeds the value of the table $\chi^{2}$. In this case, at least one of the instrument variables used is associated with the error term and therefore the instrument variable estimation based on the selected instruments is invalid (Gujarati, 2004).

Autocorrelation occurs due to the presence of a lagged dependent variable between regressions and unit effects that characterize the heterogeneity between individuals (Baltagi, 2005). A possible solution in the case of autocorrelation is to use maximum probability or instrument variables (Verbeek, 2004).

For the generalized moments estimator to be effective, there should be no quadratic autocorrelation. To test the validity of this assumption, autocorrelation must be tested.

The hypotheses used in the autocorrelation test of Arellano and Bond are established as follows;

$\mathrm{H}_{0}$ : There is no second-order autocorrelation between error terms.

$\mathrm{H}_{1}$ : There is second-order autocorrelation between error terms.

The biggest disadvantage of the Arellano and Bond method is that it increases the number of missing data even more when working with unbalanced panels. In addition, this method is insufficient if the number of lagged variables in the model is high.

\section{Application}

\section{Data Set and Method}

In this study, in order to examine the factors affecting child labor in developing countries, MINT countries were discussed and the factors causing child labor were determined with dynamic panel data models using the data of these countries for the period 1990-2018. Human development index (HDI) dependent variables, population growth (PG), primary education duration (PED), school enrollment rate (SER), and labor force participation rate (LFP) variables were added to the model as independent variables. Stata 14 package program and Rstudio program were used in the study. The data have been compiled from the World Bank. 


\section{Empirical Findings}

Before starting the analysis, descriptive statistics regarding the variables were calculated and are presented in Table 1.

Table 1

Descriptive Statistics for the Panel Data Set Examined

\begin{tabular}{lcccccccc}
\hline Variables & Obs & Min & 1st.Qu & Median & Mean & 3rd Qu & Max & Std.Err \\
\hline PG & 116 & 1.091 & 1.354 & 1.538 & 1.735 & 2.042 & 2.681 & 0.6329483 \\
PED & 116 & 4.000 & 5.750 & 6.000 & 5.692 & 6.000 & 6.000 & 1.742222 \\
SER & 116 & 78.66 & 99.27 & 105.84 & 102.52 & 109.16 & 114.34 & 5.698276 \\
HDI & 116 & 0.4500 & 0.5333 & 0.6570 & 0.6357 & 0.7150 & 0.8200 & 102.6874 \\
LFP & 116 & 45.06 & 54.45 & 60.03 & 58.93 & 62.05 & 68.01 & 58.90629 \\
\hline
\end{tabular}

According to the results obtained; the number of observations used in the study is 116. The minimum, maximum, mean, median, standard error, 1 standard deviation, and 3 standard deviation values for all variables appear. When the table is examined, the mean value and the median value are calculated close to each other in all variables. This shows us that the variables have an almost symmetrical distribution.

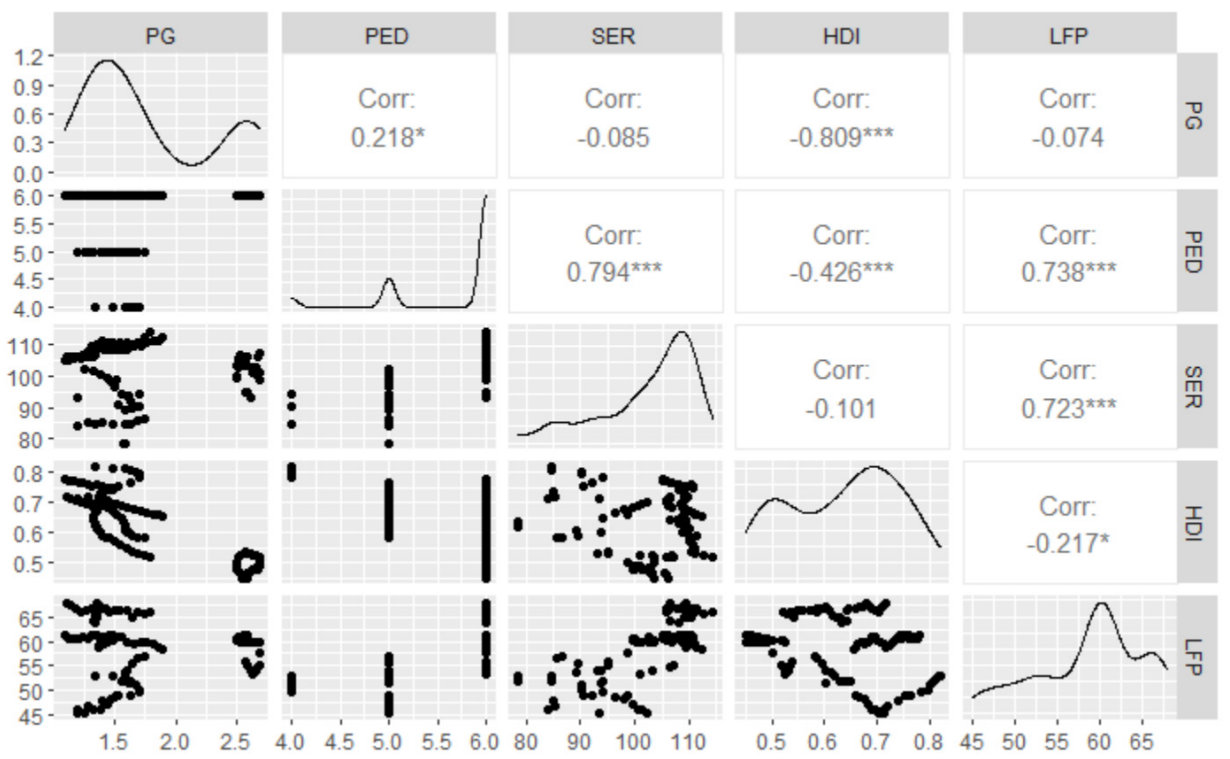

Chart 1. Pearson Correlation Coefficient

The Pearson Correlation coefficient between variables is shown in Chart 1. The correlation coefficient between population growth and primary education period was found to be 0.218 . This indicates that there is a weak positive correlation between the two variables.

On the other hand, the correlation coefficient between the human development index and population growth was found to be -0.809 . Accordingly, it can be said that 
there is a strong negative correlation between the human development index and population growth.

At this stage, it will be necessary to test whether the explanatory variables are endogenous or not. If there is a correlation between the error terms and the explanatory variables, the explanatory variables are said to be endogenous. For this purpose, residuals from the model were obtained and the correlation relationship with the explanatory variables was examined. The results are shown in Table 2.

Table 2

Correlation Relationship Between Explanatory Variables and Error Term

\begin{tabular}{lccccc}
\hline & LFP & SER & PG & PED & Residual(ut) \\
\hline LFP & 1.0000 & & & & \\
SER & 0.7228 & 1.0000 & & & \\
PG & -0.0560 & -0.0825 & 1.0000 & & \\
PED & 0.7486 & 0.7928 & 0.2175 & 1.0000 & \\
Residual(ut) & 0.0000 & 0.0000 & 0.0000 & 0.0000 & 1.0000 \\
\hline
\end{tabular}

According to the results, there is no correlation between residuals and explanatory variables. Explanatory variables are exogenous. Model estimation was made according to these results.

In Table 3, Pesaran CD cross section dependency test results, which are used to determine the presence of correlation between units, are presented.

Table 3

Pesaran CD Cross Section Dependency Test

\begin{tabular}{lcccc}
\hline Variables & CD-test & p-value & Corr & abs(corr) \\
\hline PG & 1.27 & 0.006 & 0.094 & 0.094 \\
SER & 5.03 & 0.000 & 0.375 & 0.394 \\
HDI & 10.94 & 0.000 & 0.815 & 0.815 \\
CAT & 37.39 & 0.000 & 0.928 & 0.928 \\
\hline
\end{tabular}

$$
\begin{aligned}
& \mathrm{H}_{0}: \rho_{i j}=0 \\
& \mathrm{H}_{0}: \rho_{i j} \neq 0
\end{aligned}
$$

According to the results obtained, CD test statistics, probability value, and correlation coefficient between units were calculated for the variables used in the model. The average correlation coefficient was $0.09 \%$ for PG, 38\% for SER, $0.82 \%$ for HDI, and $0.92 \%$ for LFP.

According to the calculations, the $\mathrm{H}_{0}$ hypothesis was rejected and it was concluded that there was a correlation between units. In this case, it is necessary to prefer the second-generation panel unit root tests used in the presence of correlation between units. 
After determining that the variables are not stationary in the level by examining the stationarities of the variables with Cross-sectionally augmented IPS (CIPS), which are among the second-generation panel unit root tests, their first differences were obtained and their stationarities were obtained.

Table 4

Results of Cross-Sectionally Augmented IPS (CIPS) Test

\begin{tabular}{lcccccc}
\hline \multicolumn{7}{c}{ I(0) } \\
\hline Variables & t-bar & Cv10 & Cv5 & Cv1 & Z[t-bar] & P-value \\
\hline PG & 2.610 & -2.100 & -2.220 & -2.440 & 17.281 & 1.000 \\
PED & 2.610 & -2.210 & -2.330 & -2.570 & 9.010 & 1.000 \\
SER & -2.283 & -2.210 & -2.230 & -2.570 & -1.079 & 0.140 \\
HDI & -1.281 & -2.210 & -2.230 & -2.570 & 0.988 & 0.839 \\
LFP & 2.610 & -2.100 & -2.220 & -2.440 & 17.281 & 1.000 \\
\hline & & & $\mathbf{I}(\mathbf{1})$ & & & P-value \\
\hline Variables & t-bar & $\mathbf{C v 1 0}$ & $\mathbf{C v 5}$ & $\mathbf{C v 1}$ & $\mathbf{Z}[\mathbf{t}-\mathbf{b a r}]$ & 0.000 \\
\hline PG & -2.610 & -2.100 & -2.220 & -2.440 & 17.281 & 0.000 \\
PED & -2.610 & -2.210 & -2.330 & -2.570 & 9.010 & 0.000 \\
SER & -3.743 & -2.210 & -2.330 & -2.570 & -4.088 & 0.001 \\
HDI & -3.289 & -2.210 & -2.330 & -2.570 & -3.153 & 0.000 \\
LFP & 3.630 & -2.200 & -2.220 & -2.440 & 17.281 &
\end{tabular}

According to the Im Pesaran Shin Panel unit root test results, the CIPS test results with a constant allowed and 1 delay are shown in Table 3 . According to the first part of the table, it is seen that the series are not stationary at the I (0) level as a result of the probability value of the $\mathrm{Z}$ [t-bar] statistic.

In the second part of the table, variables are found to be stable at I (1) level. Accordingly, the series are stationary, since the t-bar (CIPS) statistic is greater than the absolute value of the critical values at the 90\% (cv10), 95\% (cv5), and 99\% (cv1) confidence levels. According to the probability value of the $\mathrm{Z}$ [t-bar] statistic, it is seen that the series is stationary.

Since the error terms are considered to be heteroscedastic in the Arellano and Bond Two-Step Generalized Moments method, the model was obtained with this estimation method. First, let's test our model using Arellano and Bond's Two-Step Generalized Moment Estimator.

Table 5

Arellano and Bond's Two-Step Generalized Moments Estimator

\begin{tabular}{lcccl}
\hline HDI & Variables & $\mathbf{Z}$ & $\mathbf{P}>|\mathbf{Z}|$ & St.Errors \\
\hline L1.HDI & 0.4603982 & 6.89 & 0.000 & 0.0667918 \\
PG & -0.1168033 & -31.47 & 0.000 & 0.0037111 \\
SER & 0.0019538 & 7.22 & 0.000 & 0.0002705 \\
LFP & 0.0031105 & 5.58 & 0.000 & 0.0005572 \\
PED & 0.0565616 & 8.70 & 0.000 & 0.0 .006504 \\
L(2/.).HDI & & & &
\end{tabular}

Wald : 7056.12 Prob : 0.0000

Warning: GMM two-step standard errors are biased; robust standard errors are recommended. 
The Two-Stage Generalized Moments Estimator is shown above. According to the results, the variables are statistically significant. The Wald Test is significant. Below the coefficient table, the warning GMM two-stage standard errors should deviate, resistive standard errors are suggested is provided. Accordingly, Table 6 presents the robust standard errors and Arellano and Bond's Two-Stage GMM Estimator results.

Table 6

Results of Arellano and Bond's Generalized Moments Estimator (with Robust Standard Errors)

\begin{tabular}{lcccc}
\hline HDI & Variables & $\begin{array}{c}\text { WC-Robust } \\
\text { Std . Err. }\end{array}$ & $\mathbf{Z}$ & $\mathbf{P}>|\mathbf{Z}|$ \\
\hline L1.HDI & 0.4603982 & 0.1286028 & 3.58 & 0.000 \\
PG & -0.1168033 & 0.007011 & -16.66 & 0.000 \\
SER & 0.0019538 & 0.0004678 & 4.18 & 0.000 \\
LFP & 0.0031105 & 0.0009718 & 3.20 & 0.001 \\
PED & 0.0565616 & 0.0122297 & 4.62 & 0.000 \\
L(2/.).HDI & & & &
\end{tabular}

Wald : 2315.41 Prob : 0.0000

* The number of instrument variables was determined to be 3 .

According to the results obtained from Table 4, the dynamic panel data model was created as follows:

$$
\Delta \mathrm{HDI}_{\mathrm{i}, \mathrm{t}}=\Delta \mathrm{HDI}_{\mathrm{i}, \mathrm{t}-1}+\Delta \mathrm{PG}_{\mathrm{i}, \mathrm{t}}+\Delta \mathrm{SER}_{\mathrm{i}, \mathrm{t}}+\Delta \mathrm{LFP}_{\mathrm{i}, \mathrm{t}}+\Delta \mathrm{PED}_{\mathrm{i}, \mathrm{t}}+\Delta \mathrm{v}_{\mathrm{i}, \mathrm{t}}
$$

The HDI, which is the 2-period delay of the HDI, is L (2/.). HDI, which is the $\mathrm{HDI}_{\mathrm{it}-2}$, is used as a tool instead of the $\mathrm{HDI}_{\mathrm{it}-1}$, which is among the independent variables and is the lagged value of the dependent variable.

As a standard, in the first difference model, D.PG $(\triangle P G)$ instead of PG, D.SER $(\triangle \mathrm{SER})$ instead of SER, D.LFP $(\triangle \mathrm{LFP})$ instead of LFP, and D.PED $(\triangle \mathrm{PED})$ instead of PED were used.

As can be seen, the lagged dependent variable is significant in explaining the human development index and its sign is positive. Likewise, the variable of population growth and the number of primary school students is also statistically significant with a negative sign. School enrollment and labor force participation rate variables were also found to be statistically significant with positive signs.

When looking at the results of the Wald Test conducted to test the co-significance of the whole model, it can be said that the model is generally significant.

The results of the Wu-Hausman Endogeneity Test to test the endogeneity of the lagged dependent variable, the autocorrelation test of Arellano and Bond to test the presence of autocorrelation, and the Sargan test to test the overidentification constraints are given in Table 7. 
Wu-Hausman EndogeneityTest

Durbin Score : $2.06254(\mathrm{p}=0.1510)$

Wu-Hausman: $1.76105(\mathrm{p}=0.1975)$

Arellano - Bond Test

\begin{tabular}{ccc} 
Order & \multicolumn{1}{c}{$\mathrm{Z}$} & Prob $>\mathrm{z}$ \\
1 & -3.2139 & 0.0013 \\
2 & 0.74812 & 0.1232 \\
& Sargan Test & \\
\hline
\end{tabular}

Chi2 : 14.073 Prob : 0.0009

According to Durbin's Score and Wu-Hausman test results used to test internality, the lagged dependent variable is exogenous. If the selected instrumental variables are not exogenous, residuals and independent variables will be correlated.

The Sargan Test tests the validity of over-identification restrictions, that is, the validity of the tools used. According to the probability value results, it is seen that the over-identification restrictions are not valid, that is, the tools are invalid.

As is known for the generalized moment method, there must be no second-order autocorrelation for parameter estimators to be effective. For this reason, the existence of autocorrelation should be examined after the estimation of the models. For this purpose, in the Arellano and Bond tests, which will be used to test the existence of autocorrelation, the presence of both 1st and 2nd order autocorrelation is tested. As it is known, it is not very important that there is a first-order autocorrelation. But for Generalized Moments estimators to be effective, there must be no 2nd order autocorrelation. Here, it was seen that the $\mathrm{z}$ test statistic used to test the existence of 2 nd order autocorrelation was insignificant. In the first order, there is negative autocorrelation as expected.

\section{Conclusion}

Child labor is an important social problem not only in underdeveloped countries but also in developed countries that have completed the industrialization process. However, child labor is more common in underdeveloped countries. The concept of child labor is formed by the combination of many factors that affect each other.

It shows that the problem of child labor cannot be handled differently from the socio-economic problems of the country and that the measures for a solution require wide-ranging policies.

Education and school are the most effective tools used to end child labor. In this context, it should be aimed to spread basic education and vocational education. Education costs should be brought to a level that poor families can also bear. In order to solve the problem of child labor, it is necessary to provide basic services such as 
job opportunities, health, education, social security, housing to poor families, and to reduce individual and regional differences in income and wealth distribution.

The most important reason for children to take part in working life is poverty. As long as poverty is not prevented, it is impossible to completely eradicate child labor. The prevalence of child labor in underdeveloped or developing countries in the world today confirms this. In a period where the distribution of income is further deteriorating at the global level and inequality is increasing, policies to reduce child labor will not easily reach their target.

It seems partly possible to reduce child labor if attention is paid to development policies that address problems including the exclusion of children from working life, unemployment, poverty, lack of education of families and traditional perspectives, and defects in the education system.

As a result, child labor is not a single problem and cannot be solved by evaluation alone. International societies need to realize that if we cannot protect our children, we cannot protect our development.

Hakem Değerlendirmesi: Dış bağımsız.

Çıkar Çatışması: Yazar çıkar çatışması bildirmemiştir.

Finansal Destek: Yazar bu çalışma için finansal destek almadığını beyan etmiştir.

Peer-review: Externally peer-reviewed.

Conflict of Interest: The author has no conflict of interest to declare.

Grant Support: The author declared that this study has received no financial support.

\section{References}

Akay, E. Ç. (2018). Dinamik Panel Veri Modelleri. S. Güriş içinde, Uygulamalı Panel Veri Ekonometrisi (s. 105-129). İstanbul: DER Yayınlar1.

Akbulut, H. (2013). Transfer Harcamaları ve Büyüme İlişkisi:Gelişmekte Olan Ülkeler İçin Dinamik Panel Veri Analizi. Doktora Tezi, Hacettepe Üniversitesi Sosyal Bilimler Enstitüsü, s. 117.

Arellano, M., \& Bond, S. (1991). Some Tests of Specification for Panel Data : Monte Carlo Evidence and an Application to Employment Equations. Review of Economic Studies, 277-297.

Ataseven, A., \& Bakış, Ç. (2016). İnsani Gelişme Türkiye Kamuoyu Araştırması Raporu. İstanbul: İnsani Gelişme Vakfi.

Avşar, Z., \& Ögütoğulları, E. (2012). Çocuk İşçiliği ve Çocuk İşçiliği ile Mücadele Stratejileri. SOSYAL GÜVENLIK DERGISII, 9-40.

Baland, J.-M., \& Robinson, J. A. (2000). Is Child Labor Inefficient? Journal Of Palitical Economy.

Baltagi, B. H. (2005). econometric analysis of panel data. England: John Wiley Sons, Ltd.

Basu, K., \& Hoang, P. (1998). The Economics of Child Labor. The American Economic Review, 412-427. 
Berigel, S., \& Eroğlu, İ. (2019). Türkiye' de Çocuk İşçiliğinin Dinamikleri. Sosyal Bilimler Araştırmaları Dergisi, 39-56.

Bulutay, T. (1995). Türkiye'de Çalışan Çocuklar. Ankara: T.C. Başbakanlık Devlet İstatistik Enstitüsü DİE.

Choi, C. (2010). The effect of the Internet on service trade. Economics Letters, 102-104.

Çöpoğlu, M. (2018). Türkiye'de Çocuk İş̧̧iliği. Iğdır Üniversitesi Sosyal Bilimler Dergisi, 357-398.

Edmonds, E. V., \& Pavcnik, N. (2005). The Effect of Trade Liberalization on Child Labor. Journal of International Economics, 401-419.

Efe, H., \& Uluoğlu, S. A. (2015). Dünyada Çocuk İşçiliğiyle Mücadelede Gelinen Nokta ve Geleceğe Dair Bazı Öngörüler. Eğitim Bilim Toplum Dergisi, 46-72.

Erbay, E. (2013). Türkiye'de Çocuk İşçiliğinin Büyük Resmi. Toplum ve Sosyal Hizmet, 157-167.

Erdil, E., Türkcan, B., \& Yetkiner, H. I. (2009, January). Does Information and Communication Technologies Sustain Economic Growth? The Underdeveloped and Developing Countries Case. Science and Technology Policies Research Center Working Paper Series, s. 1-16.

Fooladi, M., Rahmah, F., \& Masood, I. (2012, November 12). Information and Communication Technology Use andEconomic Growth. PLoS ONE, s. 1-7.

Gujarati, D. (2004). Basic Econometrics. Newyork: The McGraw-Hill Companies.

Hayaloğlu, P. (2015). Kırılgan Beşli Ülkelerinde Finansal Gelişme ve Ekonomik Büyüme İlişkisi: Dinamik Panel Veri Analizi. Ekonomik ve Sosyal Araştırmalar Dergisi, 131-144.

Khadraoui, N. (2012). Financial Development and Economic Growth: Static and Dynamic Panel Data Analysis. International Journal of Economics and Finance, 94-104.

Kooshki, F. M., \& Rahmah, I. (2011, 12 25). International Proceedings of Economics Development and Research. "The Impact of Information and Communication Technology Development on Economic Growth": http://www.ipedr.com adresinden alınd1

Kulaksız, Y. (2014). Yoksulluk Bağlamında Çocuk İşgücü. Çalışma Dünyası Dergisi, 91-111.

Osment, L. (2014). Child Labour; the Effect on Child, Causes and Remedies to the Revolving Menace. Sweden.

Roodman, D. (2006, Kasim). How to Do xtabond2:An Introduction to "Difference" and "System" GMM in Stata . The Center for Global Development, s. 1-42.

Srivastava, K. (2011). Child labour issues and challenges. Industrial Psychiatry Journal, 1-3.

Taş, H. Y., \& Abbasigil, S. Ö. (2016). Çocuk İşçiliği Sorunu: Türkiye-Almanya-Pakistan Karşılaştırması. HAK-IŞ Uluslararası Emek ve Toplum Dergisi, 25-46.

Tatoğlu, F. Y. (2013). Illeri Panel Veri Analizi. İstanbul: Beta.

Tunçcan, N. (1999). Çocuk İşçiliği: Nedenleri, Boyutları ve Küreselleşen Dünyadaki Konumu. İ.Ü. İktisat Fakültesi Yayınlanmamış Yüksek Lisans. İstanbul.

Verbeek, M. (2004). A Guide to Modern Econometrics. John Wiley Sons,Ltd, s. 121.

Zeren, F., \& Ergun, S. (2010). AB’ye Doğrudan Yabancı Yatırım Girişlerini Belirleyen Faktörler: Dinamik Panel Veri Analizi. Business and Economics Research Journal, 67-83. 